\title{
How Elite Partisan Cues Affect International Organization Legitimacy
}

\author{
Lisa Dellmuth and Jonas Tallberg, Stockholm University
}

\begin{abstract}
While domestic political parties engage in growing contestation over international organizations (IOs), we know little about the effects of party cues on citizen perceptions of IO legitimacy. This paper is an effort to address this gap. Theoretically, we develop an argument for why citizens should be responsive to party cues when forming legitimacy beliefs toward IOs, and when those effects should be particularly strong. Empirically, we present the findings from two vignette experiments in the US and Germany, focused on party cues regarding military spending on NATO and refugees accepted under the UN convention. We find that citizens draw on party cues when developing legitimacy beliefs toward IOs, but that these effects are conditioned by political context and individual characteristics. Party cue effects are stronger in the more polarized US political environment and for citizens with more positive attitudes toward international cooperation to start with. Our findings have important implications for research on elite communication and IO legitimacy.
\end{abstract}

Prepared for the 2020 Virtual Annual Meeting of the American Political Science Association 
How do domestic party cues affect citizens' legitimacy beliefs toward international organizations (IOs)? Some of the most prominent communicators about the merits and demerits of IOs are domestic politicians. Consider well-known critics of IOs such as Rodrigo Duterte of the Partido Demokratiko Pilipino in the Philippines, Marine Le Pen of the National Rally in France, and Donald Trump of the Republicans in the US, or famous defenders of IOs such as Angela Merkel of the Christian Democratic Party in Germany, Carl Bildt of the Moderate Party in Sweden, and Fernando Cardoso of the Brazilian Social Democratic Party. IOs are not only contested among elites at the international level, but also in domestic party debates on issues such as climate change, debt reduction, free trade, and regional integration.

Yet, to date, the effects of party cues on perceptions of IO legitimacy have received scant attention in existing research. By legitimacy, we mean the extent to which citizens perceive an IO to exercise authority appropriately (Tallberg et al. 2018; Zürn 2018). ${ }^{1}$ In political communication, a rich body of literature has examined how party cues affect public opinion on domestic political issues, especially in the United States (US) (e.g., Levendusky 2010; Leeper and Slothuus 2010; Slothuus and de Vreese 2010; Druckman et al. 2013; Brookman and Butler 2017; Bisgaard and Slothuus 2018). Beyond the domestic setting, existing research is limited to a number of studies on how party cues shape public support for the European Union (EU) specifically (e.g., Hooghe and Marks 2005; Maier et al. 2012; Torcal et al. 2018), and on the effects of party cues on US public opinion regarding foreign policy (e.g., Berinsky 2009; Guisinger and Saunders 2017; Cavarini and Feedman 2019).

In International Relations, recent years have seen an upsurge of interest in the legitimation and delegitimation of IOs by various actors (Tallberg and Zürn 2019). However, this literature has tended to overlook domestic political parties, focusing instead on international elites, notably, non-state actors (O'Brien et al. 2000; Kalm and Uhlin 2015;

\footnotetext{
${ }^{1}$ This conceptualization conforms to a sociological understanding of legitimacy (Suchman 1995; Weber 1922[1978]). A normative understanding, by contrast, derives an organization's legitimacy from its conformance to values such as justice and democracy (Buchanan and Keohane 2006).
} 
Gregoratti and Uhlin 2018; Maliniak et al. 2020), member states (Hurd 2007; Morse and Keohane 2014; Binder and Heupel 2015; Dellmuth and Tallberg 2020; Stephen and Zürn 2019), and IOs themselves (Steffek 2003; Zaum 2013; Gronau and Schmidtke 2015; EckerEhrhardt 2018; Zürn 2018; Dingwerth et al. 2019; Rocabert et al. 2019; von Billerbeck 2020).

This paper is an effort to bridge this gap by examining the effects of party cues on IO legitimacy beliefs. It aims to bring partisan politics into the debate over IO legitimacy and to shed new light on the importance of party cues for attitudes toward international cooperation. Identifying whether and when communication by political parties affects citizens' perceptions of IO legitimacy is essential. With the rise of anti-globalist populist parties in many countries around the world, IOs have become politically contested like never before (De Vries et al. forthcoming). Getting a better grasp of how political parties shape legitimacy beliefs toward IOs can tell us something about the potential effects of this contestation for international cooperation, dependent on domestic public support (Putnam 1988).

Theoretically, we develop an argument for why citizens should be responsive to cues from political parties when forming legitimacy beliefs toward IOs, and when those effects should be particularly strong or weak. Our argument draws inspiration from cueing theory as developed in the domestic context (Bullock 2011; Druckman et al. 2013), extending this logic to the specific conditions of global politics. We derive three specific hypotheses, focused on general effects of party cues on IO legitimacy beliefs and conditioning effects arising from partisan identification and political polarization.

Empirically, we test these hypotheses through two vignette experiments conducted in the US and Germany, which offer variation in the degree of political polarization. The two identically designed experiments appeared in the same survey. One experiment focuses on party cues regarding military spending on the North Atlantic Treaty Alliance (NATO), and 
the other experiment on party cues regarding refugees accepted under the United Nations (UN) refugee convention.

We find that citizens draw on party cues when developing legitimacy beliefs toward IOs, but that these effects are conditioned by the political context and individual characteristics. Party cues matter almost exclusively in the US, and hardly at all in Germany. This result suggests that party cues sway legitimacy beliefs more strongly in more polarized political environments. In addition, citizens who already have more positive opinions of the two IOs and the issues at hand are more easily influenced by party cues. This indicates that party cues are particularly influential among more positively engaged citizens, but do not get through to citizens who care little for international cooperation.

\section{Theory and hypotheses: Effects of party cues on IO legitimacy beliefs}

We build on cueing theory to advance an argument about why party cues should affect citizens' legitimacy beliefs in relation to IOs, and when those effects should be particularly strong or weak. Our argument rests on the assumption that citizens rarely have stable, consistent, and informed political attitudes, and therefore may be susceptible to elite communication (Druckman and Lupia 2000; Chong and Druckman 2007; Busby et al. 2018). Cueing theory suggests that elite cues shape people's opinions on an issue by simplifying choices for them, thus allowing them to overcome informational shortfalls (Zaller 1992; Druckman and Lupia 2000; Bullock 2011).

An extensive literature in American and Comparative Politics shows that cues from political parties are particularly influential in shaping public opinion (Levendusky 2010; Slothuus and de Vreese 2010; Druckman et al. 2013; Leeper and Slothuus 2010; Brookman and Butler 2017). The general idea is that people tend to follow cues from parties they sympathize with, while neglecting cues from parties they disagree with. This expectation is 
rooted in the dual recognition that citizens demand cognitive short-cuts to form political opinions and that parties fulfil central roles in structuring the choices that exist in domestic politics (Sniderman 2000; Leeper and Slothuus 2010).

The theory focuses specifically on so called "partisans," i.e., those citizens who identify with or lean toward a specific political party (Druckman et al. 2013, 61). In the words of Goren et al. (2009, 806): "When someone hears a recognizable partisan source advocating some position, her partisan leanings are activated, which in turn lead her to evaluate the message through a partisan lens. If the cue giver and recipient share a party label, the latter will trust the former and accept the message without reflecting much on message content. But if the cue giver and recipient lie across the partisan divide, the recipient will mistrust the source and reject the message, again without much reflection."

We expect that party cues not only shape opinion formation in domestic politics, but also international politics, as citizens form opinions of IOs. Citizens listen specifically to those elites they trust when they develop opinions about political issues. While citizens may listen to member states, NGOs, and IOs on issues of global governance (Dellmuth and Tallberg 2020), we consider it likely that political parties, too, shape citizens' opinions.

Political parties not only communicate about domestic concerns, but often take positions on international issues involving IOs as well. Given the central role that parties occupy in structuring the choices that citizens confront, we expect their influence to extend to international issues as well. Evidence from the one IO where such dynamics have been systematically studied - the EU - suggests that this expectation is reasonable (Hooghe and Marks 2005; Maier et al. 2012; Torcal et al. 2018).

We develop three hypotheses about the effects of party cues on legitimacy beliefs toward IOs. The first hypothesis expresses the general expectation that party cues affect legitimacy beliefs toward IOs when citizens identify with that political party. Research on 
party cues in the domestic context suggests two complementary ways in which this happens (Leeper and Slothuus 2010). One perspective conceives of party cues as informational shortcuts that provide simple information which can guide citizens to form preferences (Carmines and Kuklinski 1990; Sniderman et al. 1991; Lau and Redlawsk 2001; Levendusky 2010). Citizens specifically follow the cues of those parties they tend to sympathize with, since the positions of those parties likely approximate the opinions citizens would have developed had they invested time and effort to form an opinion on their own. The other perspective suggest that party cues are influential because they activate citizens' longstanding party loyalties and lead them to engage in motivated reasoning (Campbell et al. 1960; Taber and Lodge 2006; Slothuus and de Vreese 2010; Lavine et al. 2012; Druckman et al. 2013). When citizens identify with a party, they are emotionally attached to it and will interpret new information in ways that confirm this affective relationship. The psychological process through which this occurs is motivated reasoning - the tendency to seek out information that confirms prior beliefs, to view evidence consistent with prior opinions as stronger, and to spend more time arguing against evidence inconsistent with prior opinions (Druckman et al. 2013, 59). While emphasizing different mechanisms, both approaches lead to the expectation that party cues will be effective in shaping the opinions of partisans.

H1: When citizens receive a message sponsored by a party they identify with and a conflicting message sponsored by another party, their legitimacy beliefs will be more likely to move in the direction of the message conveyed by the party they identify with than in the direction of the other party's message.

Yet party cues may be varyingly effective under different conditions. This leads us to formulate two additional hypotheses (cf. Druckman et al. 2013). To begin with, we expect the 
strength of the party cue effect to depend on the degree to which citizens lean toward a particular party, i.e., the level of party identification. When citizens identify more with a party, cues are more likely to present efficient informational short-cuts and to activate partisan loyalties, making citizens more likely to follow cues from this party. Conversely, when citizens identify less with a party, cues offer less certain informational guides for citizens and mobilize loyalties less, making citizens less likely to follow cues from this party.

H2: The effect of party cues predicted in H1 will be stronger among citizens with a stronger partisan identity than among citizens with a weaker partisan identity.

In addition, we expect the strength of the party cue effect to depend on the level of party polarization on the particular issue (Levendusky 2010; Druckman et al. 2013). In this context, party polarization has two components: the ideological distance between the parties on the specific issue, and the ideological homogeneity within each party on this issue (Levendusky 2010, 118). Greater polarization entails that parties send clearer signals to citizens on where they stand. Thus, when issues are more polarized (i.e., parties are further apart and more ideologically homogenous), citizens are more likely to follow cues from party elites whose partisan orientation they share than when issues are less polarized (i.e., parties are positioned closer to each other and less ideologically homogenous). A number of studies in American Politics find support for this expectation (Levendusky 2010; Nicholson 2012; Druckman et al. 2013).

H3: The effect of party cues (H1) will be stronger when party polarization on an issue is high (parties are further apart and more ideologically homogenous) than when party polarization 
on an issue is low (parties are positioned closer to each other and less ideologically homogenous).

\section{Research design}

We test these hypotheses through two vignette experiments, designed to assess whether and when party cues shape legitimacy beliefs toward IOs. Both experiments appeared in the same survey, conducted online among nationally representative samples of German and American respondents $\left(\mathrm{N} \approx 2000\right.$ per country) and implemented by YouGov during May $2019 .^{2}$

While many experiments of party cue effects in the domestic context focus on a single country, usually the US, we opted for two countries, as we wanted to assess our hypotheses in political systems with varying levels of party system polarization (Dalton 2008) and mass opinion polarization (Lupu 2015). It can be expected that party cues have stronger effects in countries with a higher level of party system and mass opinion polarization (such as the US) compared to countries with a lower level of party system and mass polarization (such as Germany). In addition, this selection ensured that the two countries were similar across several important contextual conditions, including political system, economic development, political centrality in the examined IOs, and Internet penetration.

In terms of political parties, we selected the two major parties in the federal parliament in both countries: the Democrats and the Republicans in the US, and the Christian Democratic Union/Christian Social Union (CDU/CSU) and the Social Democratic Party (SPD) in Germany. In Germany, these are historically the two largest parties. Although they have lost considerable electoral support over the past decade due to a strengthening of the Green party and the Alternative for Germany (AfD), as we discuss below, CDU/CSU and SPD are still perceived as the two largest catch-all parties (Volksparteien).

\footnotetext{
${ }^{2}$ The experiments are pre-registered with EGAP (No. 20190507AB). See: http://egap.org/registration/5712.
} 


\section{Issue selection and frames}

Our ultimate interest is the effect of party cues on people's legitimacy beliefs toward IOs. While one option would have been to formulate vignettes that focus directly and exclusively on IOs, we chose a different strategy. Usually, IOs are invoked in domestic political debates in relation to specific political issues, rather than as objects in themselves. For instance, the IMF is discussed in the context of financial stability, crises measures, and macroeconomic adjustment. Likewise, the UNFCCC is debated in association with climate change, emissions reductions, and adaptation measures. In addition, political parties seldom communicate political positions on the legitimacy of IOs per se, beyond supporting or contesting a state's membership in an IO. We therefore chose to formulate vignettes that invoke IOs in the context of specific political issues, expecting the party cues expressed through these vignettes to sway people's legitimacy beliefs toward the respective IOs.

One experiment focused on party cues regarding military spending on NATO, and the other experiment on party cues regarding reductions in the number of refugees accepted under the UN's refugee convention. These two issues share several features that make them well suited to test our hypotheses (Druckman et al. 2013). First, both issues received attention in public debates in Germany and the US prior to our study, as we discuss below. Second, both issues involved multiple considerations, such that parties and citizens could adopt different positions and opinions. Third, both issues were such that the main parties in the US and Germany tended to hold different positions, but not persistently dramatically opposed positions, which allowed our treatments to vary the level of party polarization on the specific issues.

To substantiate vignette formulation, we conducted a systematic content analysis using two large newspapers: The New York Times in the US and Die Zeit in Germany. The aim was 
to distil the main arguments that we could assign to the political parties in the vignettes about the respective IOs, and to get information about the political polarization of the issue during the two years preceding data collection (2017 and 2018) (cf. Druckman et al. 2013; Appendix B). This content analysis allowed us to identify the main arguments that the parties were using in relation to these specific issues. We also coded how close the parties were in their opinions on both issues. We observed differences in rhetoric between the parties on the two issues, but still relatively close positions, especially in Germany. This is an advantage in terms of research design, as it allows us to present different arguments for each pair of parties on the same issue, while at the same time credibly varying the extent of party polarization on the specific issue.

Table 1 illustrates the issue frames in the NATO experiment in Germany and the US (see Appendix A for the full questionnaire). For the NATO experiment, our pro frame in Germany and the US emphasized the importance of NATO for maintaining peace, which would be undermined if restricting member state funding. On the con side, our frame in Germany concerned the trade-off between defense and welfare state expenses - both budgetary categories at the top of the German political agenda during 2017 and 2018 - while our frame in the US concerned lack of fairness in NATO funding, as the US shoulders the greater burden.

Table 1. Issue frames about NATO military spending

\begin{tabular}{|l|l|l|}
\hline & Supportive (pro) & Opposed (con) \\
\hline Germany & $\begin{array}{l}\text { Importance of NATO for } \\
\text { peace }\end{array}$ & $\begin{array}{l}\text { Trade-off between defense } \\
\text { and welfare state expenses }\end{array}$ \\
\hline US & $\begin{array}{l}\text { Importance of NATO for } \\
\text { peace }\end{array}$ & $\begin{array}{l}\text { Lack of fairness in funding } \\
\text { NATO }\end{array}$ \\
\hline
\end{tabular}


Table 2 summarizes the key content of the issue frames for the UN experiment. The pro frame stressed the need to honor Germany's or the US' commitment to protect refugees under UN refugee convention. The con frame emphasized the general costs of migration for the country.

Table 2. Issue frames about UN refugee convention

\begin{tabular}{|l|l|l|}
\hline & Supportive (pro) & Opposed (con) \\
\hline Germany & $\begin{array}{l}\text { Need to honor Germany's } \\
\text { commitment to protect } \\
\text { refugees under UN refugee } \\
\text { convention }\end{array}$ & $\begin{array}{l}\text { Costs of migration for } \\
\text { Germany }\end{array}$ \\
\hline US & $\begin{array}{l}\text { Need to honor US } \\
\text { commitment to protect } \\
\text { refugees under UN refugee } \\
\text { convention }\end{array}$ & Costs of migration for US \\
\hline
\end{tabular}

\section{Experimental conditions}

To isolate the causal effects of party cues, we randomly assigned individuals to groups that received different experimental treatments, in the form of vignettes, and a control group that did not receive any treatment. We context-adjusted vignettes according to issue and country, as described above. In addition, to make the experiment fit the German context, where the CDU/CSU are part of the same parliamentary group, but are two separate political parties, the vignettes refer to the parliamentary groups ("Bundestagsfraktionen") of the CDU/CSU and the SPD, and not to the parties. In the US, the vignettes refer to Republicans and Democrats "in Congress." The vignettes presented to the three treatment groups contained systematically varied information about the main arguments regarding the political issue, party endorsements, and party polarization on the issue (cf. Druckman 2013). 
A control group received only factual information on the issue. Treatment group 1 saw factual information on the issue, balanced frames about the main arguments on each side, and party endorsements. Treatment group 2 received factual information on the issue, balanced frames about the main arguments on each side, party endorsements, and a statement about low polarization on the issue. Finally, treatment group 3 got factual information on the issue, balanced frames about the main arguments on each side, party endorsements, and a note about high polarization on the issue. Appendix B offers examples of the specific wording of the experimental conditions, using the NATO experiment as an illustration, and shows the number of respondents in each experimental group. Respondents were assigned the same condition in both experiments, since we worried that the degree of party polarization could otherwise be confusing and since this design made it easier to assess any potential spillover effects (Transue et al. 2009; Druckman et al. 2013). The order of the experiments was block randomized for each respondent to reduce the likelihood of spillover effects from one experiment to another.

After each vignette, we asked a question measuring the outcome of interest: legitimacy beliefs toward IOs: "How much confidence do you have in [IO] on a scale from 0 (no confidence) to 10 (complete confidence)?" While legitimacy perceptions are a complex phenomenon, confidence has several advantages as an indicator. First, it aligns well with our conceptualization of legitimacy as the belief that an institution exercises its authority appropriately. Like trust, confidence picks up on a sense of institutional attachment and on a willingness to put one's judgment in the hands of that institution (Gibson et al. 2003, 361). Second, it does not integrate into the measure either potential institutional sources of legitimacy (such as the perceived fairness or effectiveness of an institution), or potential consequences of legitimacy (such as compliance with an institution's rules). While some studies use a multi-item measure with the aim to capture various complexities of legitimacy as 
a concept, these studies usually invoke a broader conceptualization of legitimacy, incorporating normative standards to be met by an institution and/or acceptance of the rules of an institution (e.g., Gilley 2006). Third, the confidence measure allows us to relate our findings to the large literature on public opinion that also employs confidence or trust as an indicator of legitimacy perceptions (e.g., Caldeira 1986; Newton and Norris 2000; Inglehart and Welzel 2005; Norris 2009; Bühlmann and Kunz 2011; Voeten 2013; Dellmuth and Tallberg 2015).

\section{Empirical analysis}

To understand the political opinion context in which these experiments were carried out, we begin by presenting descriptive data from the survey on respondents' partisanship and pretreatment opinions toward the two IOs. We then turn to the results from the two experiments.

\section{Partisanship}

Figure 1 shows the percentage of partisans in the US and Germany. In the US, about 82 percent are partisans who identify with either the Democratic or the Republican party, while, in Germany, about 77 percent identify with a political party. Only about 32 percent identify with one of the two main parties in Germany - the CDU/CSU and the SPD. Overall, then, a considerably larger share of the population identifies with one of the two main political parties in the US compared to Germany. 
US

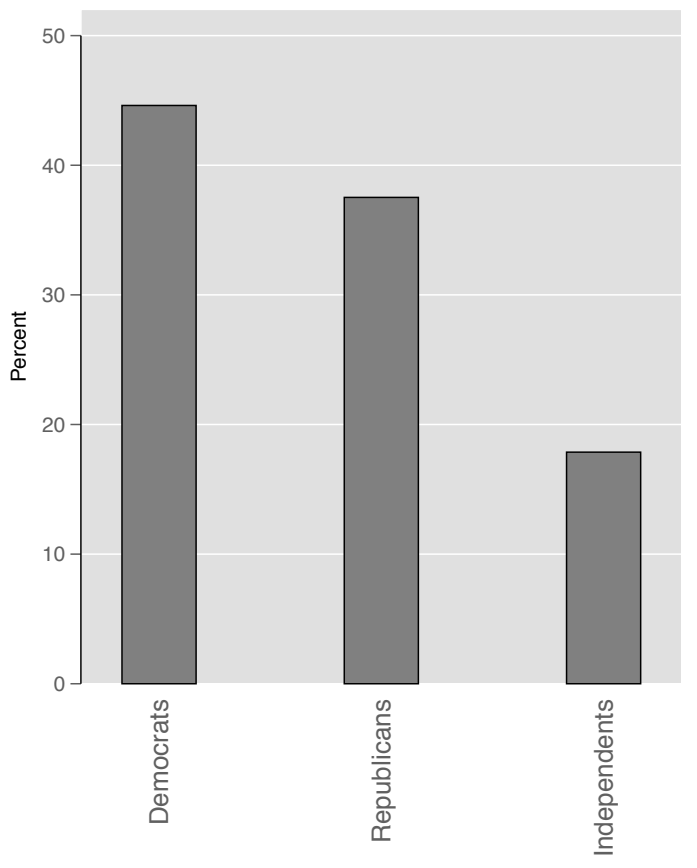

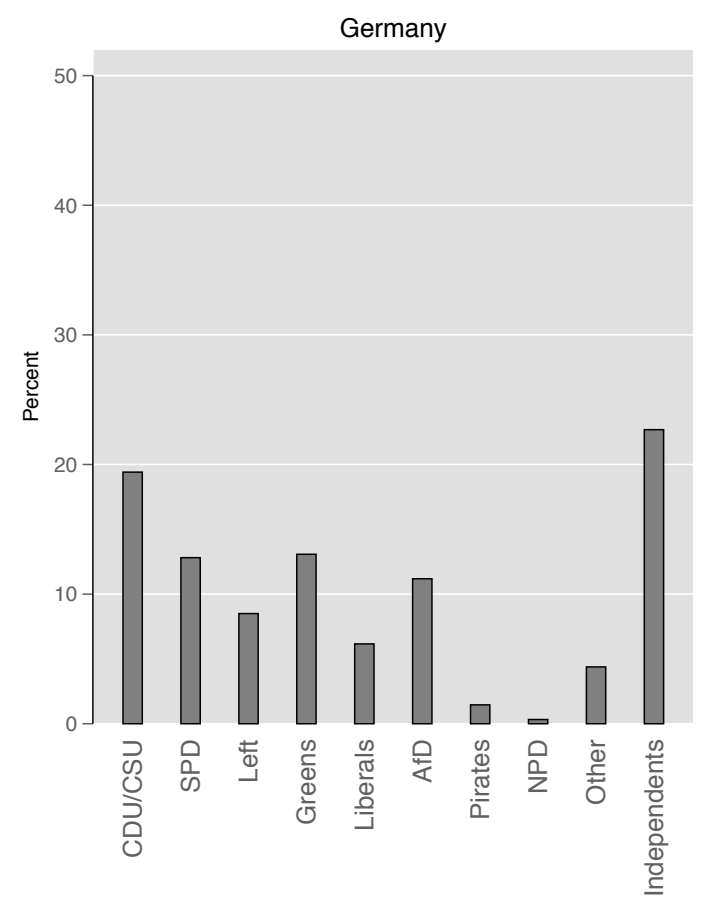

Figure 1. Percentage of partisans in the US and Germany

Note: Independents are those answering don't know to the question of partisan identification. Weighted data.

Figure 2 shows the strength of partisan identities among those who indicate that they lean toward a particular party. In the US, about 73 percent of the partisans feel very or quite close to their political party, while, in Germany, about 69 percent feel very or quite close to their political party. Thus, the distribution of partisan identity strength is quite similar in the two countries. When we further disaggregate the distribution of partisan strength in the different parties, the distribution is very similar for both parties in both countries as well (see Appendix C). 

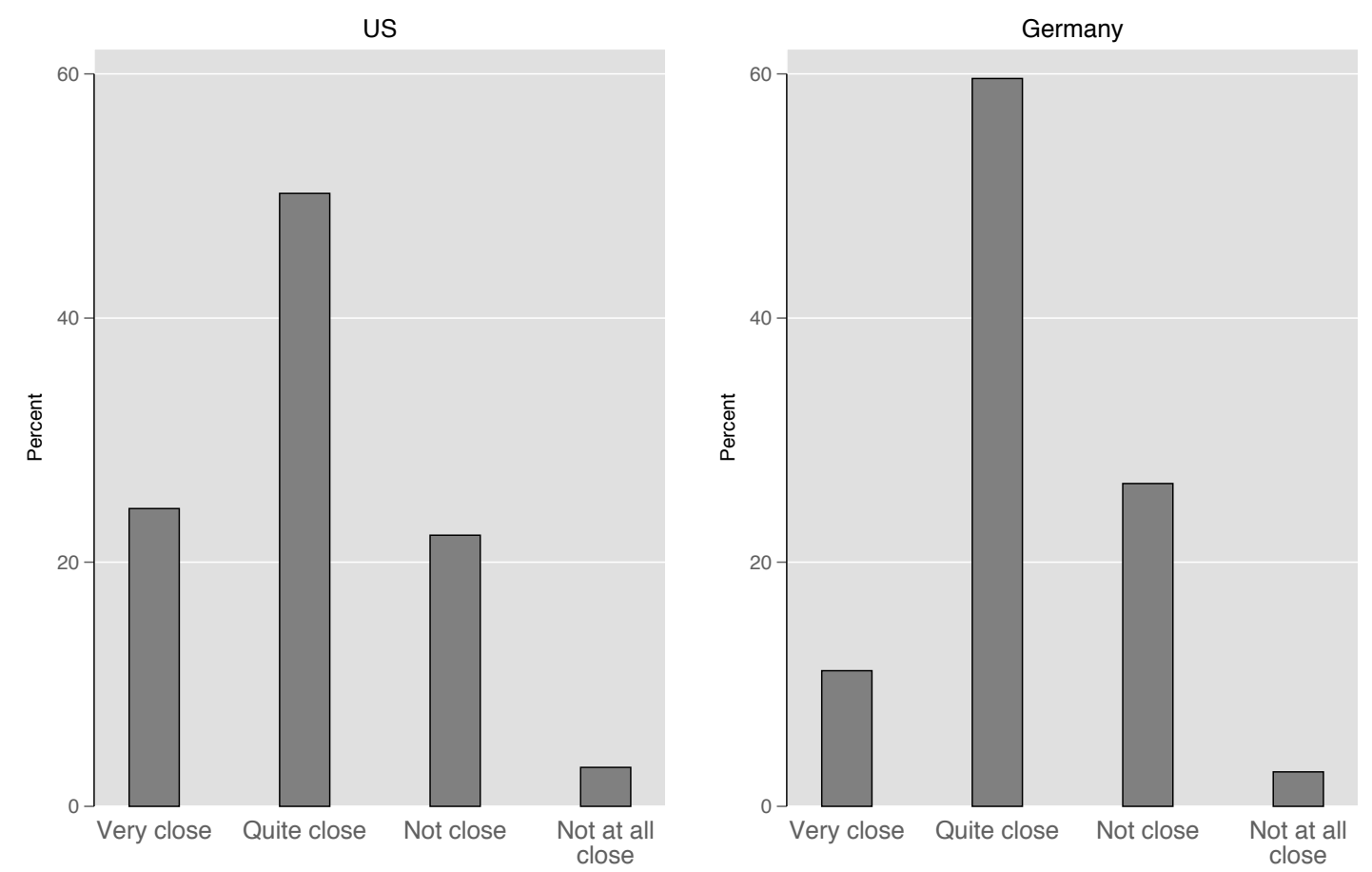

Figure 2. Partisan strength in the US and Germany

Note: This figure includes only those who indicated a partisan identification (Figure 5.1). Don't know answers coded as missing. Weighted data.

Taken together, there are more partisans in the US than in Germany, but the distribution of partisan strength among the partisans is quite similar in the two countries. The partisanship captured by these data should be understood in the context of the domestic political situation in these countries when the survey was conducted (May 2019). In the US, both party system and public opinion have become more polarized in recent years. Polarization between the Democrats and the Republicans has been fueled by redistricting, shifts in public opinion, and the relative success of more extreme position-taking. As a result, the Democratic and Republican parties are increasingly far apart and more homogenous than in the past. Polarization also applies to public opinion. Over recent decades, US citizens appear to have become more firmly situated at either end of the left-right distribution, moving away from the middle ground (Abramowitz 2010; Pew Research Center 2014). In sum, increasingly polarized parties appear to function as sorting devices for an increasingly divided public. 
In Germany, the CDU/CSU and the SPD have ruled together in a grand coalition since 2013 , leading to a reduction in the level of polarization and open conflict between the two parties. This may in turn have contributed to the rise of the populist far-right party AfD during the same period. The party first gained seats in the Bundestag in 2017, in the wake of the European migration crisis of 2015 , and soon held seats in all sixteen regional parliaments (Landtage). The rise of the AfD reflects a general ideological movement in German politics toward the right, mainly at the expense of the SPD, which has lost voters to parties both on the right and the left. As our own data on partisan identification suggests, the CDU/CSU and the SPD, once described as Volksparteien, no longer attract the large groups of partisans they once did.

\section{Pre-treatment opinions regarding IOs and issues}

We also measured respondents' pre-treatment opinions toward the IOs and issues invoked in the experiments. There are striking differences among different partisan groups in the US (Figure 3). Democrats on average view NATO as more effective and democratic than Republicans $($ diff $=1.785$ on a 11-point scale, $N=1,463, p=0.000)$ and independents (diff $=2.047, N=1,011, p=0.000)$. Likewise, Democrats view NATO as more effective and democratic than Republicans $(\operatorname{diff}=2.831, N=1,554, p=0.000)$ and independents $(\operatorname{diff}=1.983$, $N=1,078, p=0.000)$. Opinion appears especially polarized when it comes to the question of accepting refugees as a moral obligation of the US, which an overwhelming majority of Democrats tends to strongly agree with, and an overwhelming majority of Republicans tends to strongly disagree with ( $\operatorname{diff}=3.589, N=1,622, p=0.000)$. Similarly, a majority of Democrats tends to strongly disagree with the statement that defense spending should be prioritized to ensure the national security of the US, while a majority of Republicans tends to strongly agree with this statement $(\operatorname{diff}=-4.872, N=1,647, p=0.000)$. Differences between Democratic 
partisans' opinions and independents' opinions are slightly smaller than differences between Democrats and Republicans, but still substantial (diff=2.924, $N=1,174, \quad p=0.000$ for “accepting refugees" and diff $=1.358, N=1,138, p=0.000$ for "defense spending").

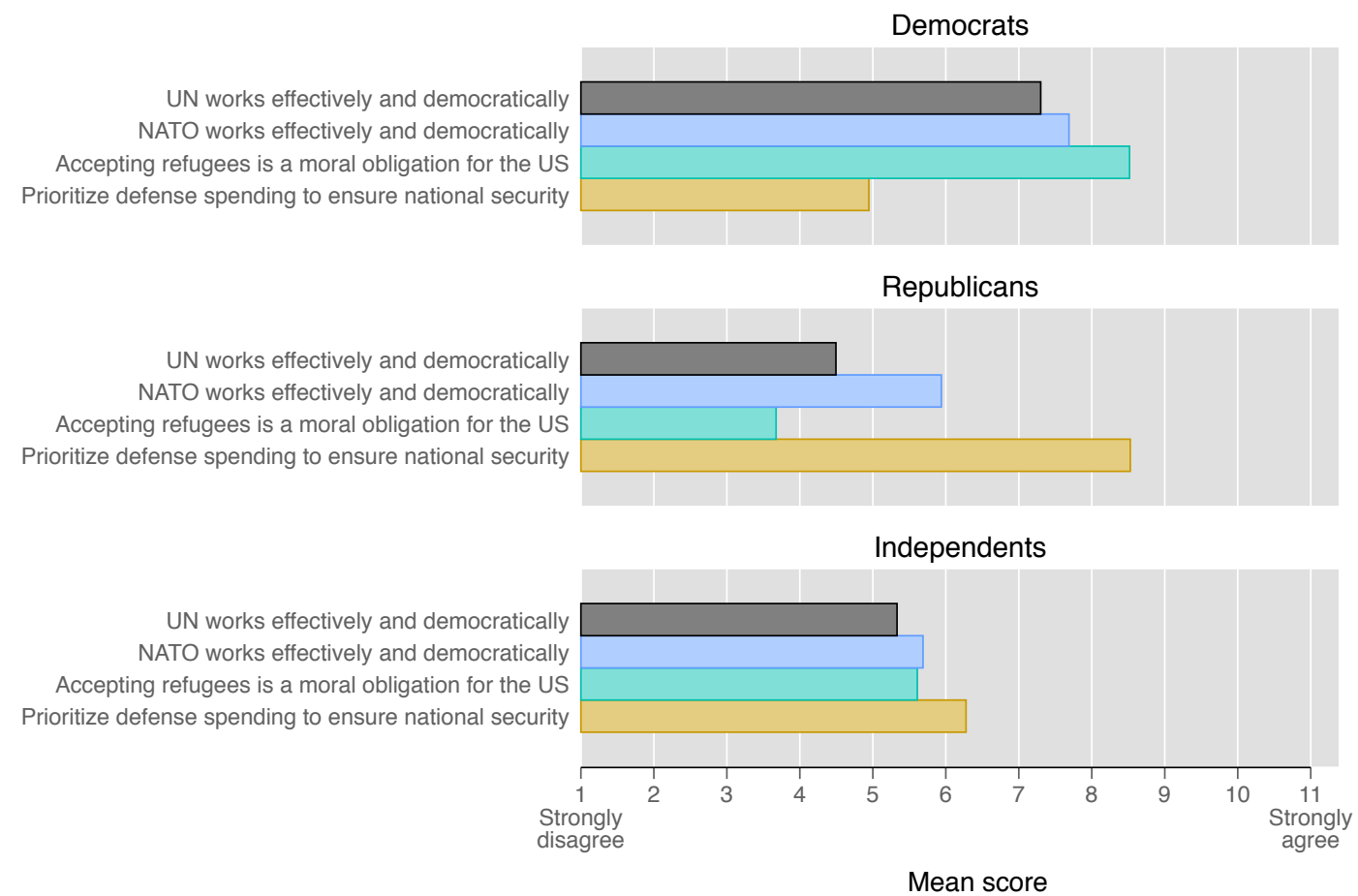

Figure 3. Pre-treatment opinions in the US, by partisan identification Note: Don't know answers coded as missing. Weighted data.

In Germany, opinion is less polarized across these four items than in the US (Figure 4). Figures for both NATO and UN support are comparable between CDU/CSU and SPD partisans. While CDU/CSU and SPD partisans do not differ on whether the UN works democratically and effectively $(N=593, p=0.760)$, SPD partisans on average believe more in NATO than CDU/CSU partisans ( $\operatorname{diff}=0.345, N=582, p=0.039)$. Interestingly, SPD partisans support the UN (diff $=0.588, N=1,361, p=0.000)$ and NATO (diff $=0.620, N=1,342, p=0.000)$ more than those who identify with other political parties. In addition, SPD partisans support the UN (diff $=0.836, N=523, p=0.000)$ and NATO (diff $=0.811, N=510, p=0.000)$ more than the independents. This suggests that SPD and CDU/CSU partisans are less polarized when 
compared to each other than when compared to citizens with other or no partisan identification.

The issue of accepting refugees as a moral obligation of Germany is slightly more contentious among Christian and Social Democrats: SPD partisans on average agree slightly more with this statement than CDU/CSU partisans (diff $=0.830, N=623, p=0.000)$, people with another partisan identification (diff=1.182, $N=1,442, p=0.000$ ), and the independents (diff=2.136, $N=628, p=0.000$ ). Conversely, prioritizing defense spending to ensure the national security of Germany is a statement that SPD partisans tend to disagree with, while CDU/CSU partisans (diff $=1.173, N=609, p=0.000$ ) and people with another partisan identification tend to agree with it (diff $=0.459, N=1,404, p=0.021)$. The difference in SPD partisan's opinion on this issue compared to independents is not statistically significant $(N=584, p=0.129)$. Taken together, despite some heterogeneity of differences in opinion between citizens with different partisan affiliations, these differences are much smaller than in the US.

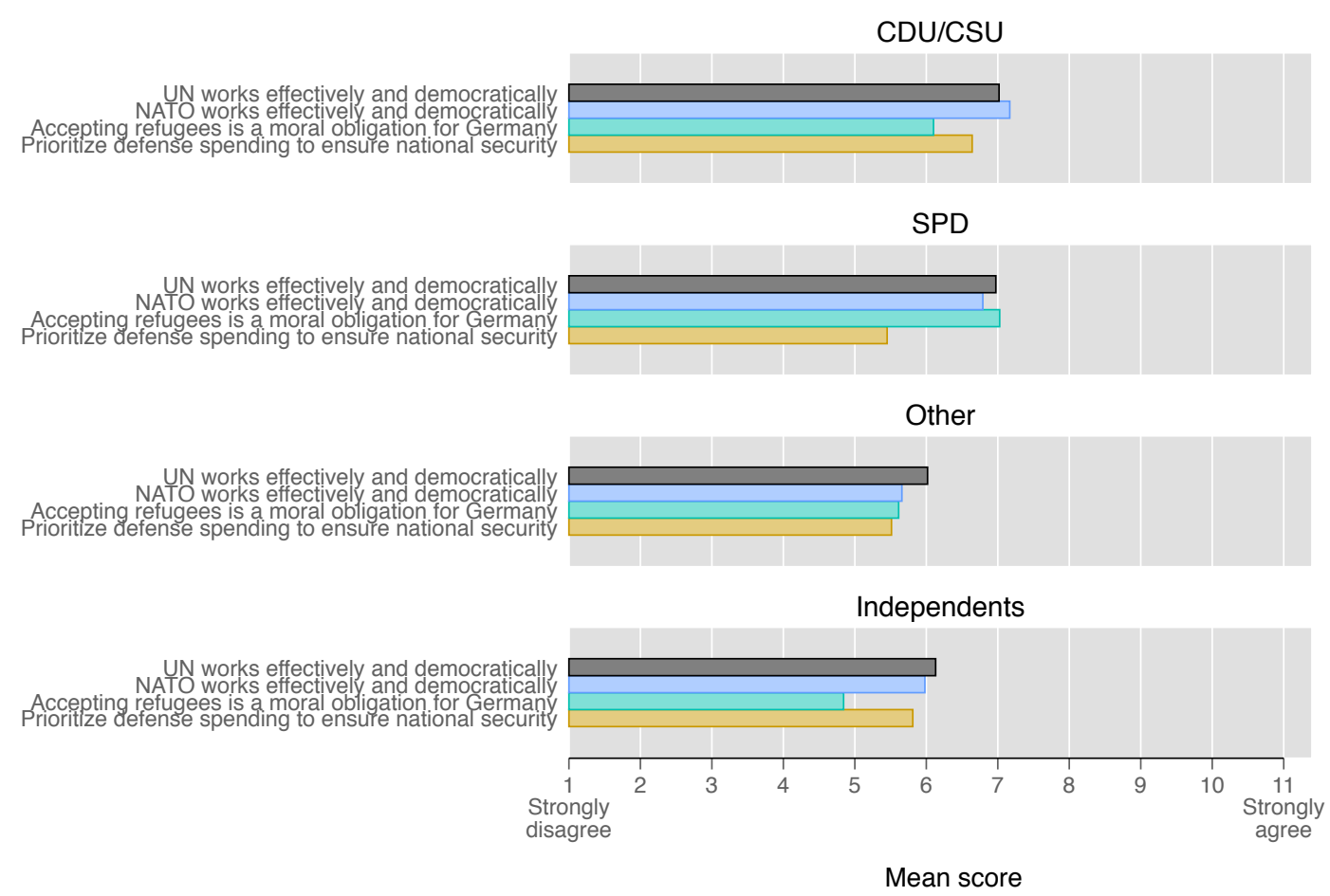

Figure 4. Pre-treatment opinions in Germany, by partisan identification Notes: Don't know answers coded as missing. Weighted data. 


\section{Hypothesis tests}

Our hypothesis tests include those respondents indicating some level of identification with a particular party (i.e., partisans), in line with our hypotheses. H1 is tested by estimating if the difference in mean confidence between treatment group 1 and the control group is significantly different from zero. $\mathrm{H} 2$ is tested by checking whether the treatment effects for respondents in treatment group 1 depend on the strength of partisan identification. Specifically, we test $\mathrm{H} 2$ through effects on confidence of interaction terms between a treatment dummy for belonging to treatment group $1(=1)$ and our variable measuring partisan identify strength. H3 is tested by assessing whether the treatment in treatment group 2 (low polarization) gives a weaker effect on confidence than the treatment in treatment group 3 (high polarization).

We discuss the results for each hypothesis in turn for each country separately, and then report a series of robustness checks. We estimate treatment effects by charting the percentage change in opinion by condition relative to the control group, which answered the two IO confidence questions without encountering other information. To this end, we use OLS regression analyses with one predictor, which are equivalent to t-tests, using weighted data. We also compare across treatment conditions when necessary to assess specific hypotheses. As our results on both IOs are very similar, we present them in tandem. We begin by reporting the results for the US, and then move on to the results for Germany.

H1 predicts that party cues will affect legitimacy beliefs toward IOs when citizens identify with the political party issuing the message. For this purpose, we separated Democrat and Republican respondents in the US to detect the different effects of party endorsements hypothesized for each set of partisans. We coded a Democrat dummy 1 if the respondent is a Democratic partisan, and 0 if they are a Republican. 
We find mixed evidence for H1. Figure 5 shows that party cues work well among Democrats in the context of both IOs. For these respondents, the treatment effects are positive and statistically significant across the board, irrespective of the information provided about the level of polarization. Among Democrats, the endorsement of NATO as a preserver of peace that needs continued funding (treatment 1) increases confidence in the IO by about 0.9 on the 11-point confidence scale, and the endorsement of the UN as a protector of refugees (treatment 1 ) increases confidence in this IO by about 0.5 . In contrast, for the Republicans, we only find a negative and statistically significant treatment effect in the context of NATO and when coupled with information about high polarization on this issue.

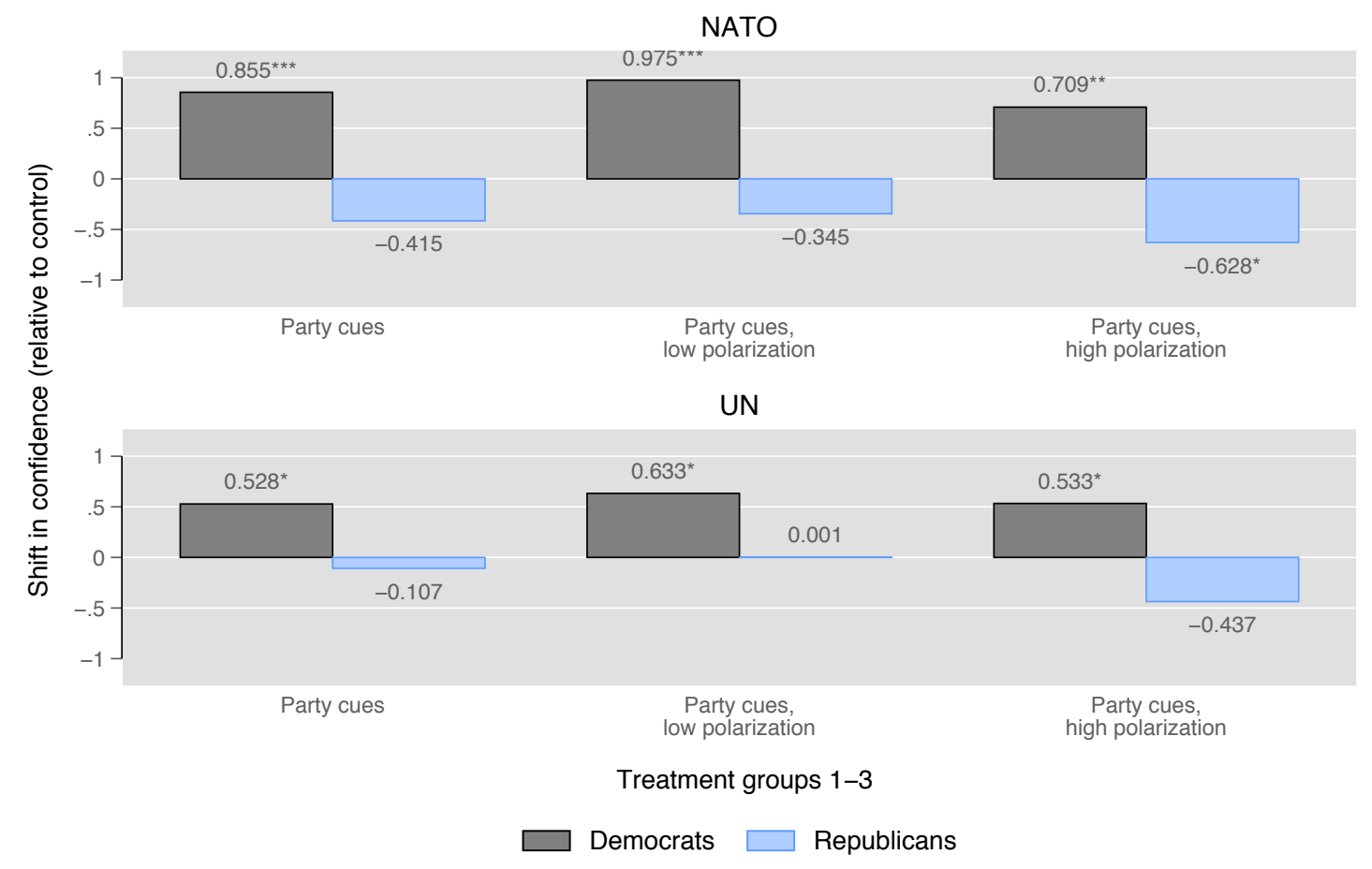

Figure 5. Treatment effects in the US

Notes: Treatment group 1 received issue frame and party endorsement; group 2 received issue frame and party endorsement in a low polarization environment; and group 3 received issue frame and party endorsement in a high polarization environment. Significance levels: $* p<0.05, * * p<0.01, * * * p<0.001$. 
$\mathrm{H} 2$ anticipated that the effects of party cues predicted in $\mathrm{H} 1$ would be stronger among those citizens with a stronger partisan identity. We again find mixed evidence for this hypothesis. Table 3 shows the results for the Democrats, while we refrain from showing the results for the Republicans, which do not offer support for this expectation in the context of any of the two IOs (see Appendix Table D1). The evidence from the Democrats corroborates $\mathrm{H} 2$ in the context of NATO, where larger treatment effects are consistently found among Democrats with a stronger partisan identity. Irrespective of the information provided about the level of polarization on the issue (treatments 1-3), respondents with a stronger identification with the Democratic Party appear more greatly affected by the party endorsement of NATO, indicated by the statistically significant and increasingly large coefficients. By contrast, we do not find evidence of such a conditional effect of partisan identity strength on confidence in the context of the UN.

H3 anticipated that the effects of party cues predicted in H1 would be stronger when issues are presented as more politically polarized among the two parties. To test this hypothesis, we estimate whether the treatment effect is significantly larger for treatment 3 (highly polarized issue) compared to the effect of treatment 2 (lowly polarized issue). The results from $t$-tests for independent samples suggest that this is not the case. We only find partial support for this expectation in the US for the Republicans, as there is statistically significant and negative effect of the party cue in the context of high polarization, but no effect in the context of low polarization. 
Table 3. Effects of party cues on legitimacy beliefs among Democrats in the US, by partisan identity strength and IO

\begin{tabular}{|c|c|c|c|c|c|c|}
\hline & \multicolumn{3}{|c|}{ NATO } & \multicolumn{3}{|c|}{$\mathbf{U N}$} \\
\hline & $\begin{array}{c}\text { Party } \\
\text { cues (1) }\end{array}$ & $\begin{array}{l}\text { Party cues, } \\
\text { low pol. } \\
\text { (2) }\end{array}$ & $\begin{array}{l}\text { Party cues, } \\
\text { high pol. } \\
\text { (3) }\end{array}$ & $\begin{array}{l}\text { Party } \\
\text { cues (1) }\end{array}$ & $\begin{array}{l}\text { Party cues, } \\
\text { low pol. } \\
\text { (2) }\end{array}$ & $\begin{array}{c}\text { Party cues, } \\
\text { high pol. } \\
\text { (3) }\end{array}$ \\
\hline \multirow[t]{2}{*}{ Treated $\times$ Not at all close } & 2.020 & 2.523 & 1.131 & 3.263 & 0.070 & 1.789 \\
\hline & $(1.814)$ & $(1.441)$ & $(1.277)$ & $(1.778)$ & $(1.792)$ & $(1.647)$ \\
\hline \multirow{2}{*}{ Treated $\times$ Not close } & $2.267^{*}$ & $3.285^{* *}$ & $2.823^{*}$ & 1.250 & 1.621 & 1.555 \\
\hline & $(1.127)$ & $(1.134)$ & $(1.131)$ & $(1.620)$ & $(1.634)$ & $(1.630)$ \\
\hline \multirow[t]{2}{*}{ Treated $\times$ Quite close } & $3.679 * * *$ & $3.211^{* *}$ & $3.309^{* *}$ & 2.314 & 2.275 & 2.233 \\
\hline & $(1.100)$ & $(1.095)$ & $(1.103)$ & $(1.602)$ & $(1.596)$ & $(1.598)$ \\
\hline \multirow[t]{2}{*}{ Treated $\times$ Very close } & $3.879 * * *$ & $4.530 * * *$ & $3.403^{* *}$ & 2.597 & $3.174 *$ & 2.486 \\
\hline & $(1.118)$ & $(1.116)$ & $(1.165)$ & $(1.612)$ & $(1.611)$ & $(1.646)$ \\
\hline \multirow[t]{2}{*}{ Constant } & $3.563 * *$ & $3.563^{* *}$ & $3.563^{* *}$ & $4.217^{* *}$ & $4.217^{* *}$ & $4.217 * *$ \\
\hline & $(1.079)$ & $(1.079)$ & (1.079) & $(1.585)$ & $(1.585)$ & $(1.585)$ \\
\hline$N$ & 324 & 317 & 311 & 325 & 324 & 316 \\
\hline Adj. $R^{2}$ & 0.150 & 0.162 & 0.106 & 0.114 & 0.144 & 0.096 \\
\hline
\end{tabular}

Notes: Entries are unstandardized coefficients with standard errors in parentheses, using an OLS regression analysis on confidence in NATO and confidence in the UN as dependent variables, respectively. Weighted data. Significance levels: ${ }^{*} p<0.05,{ }^{* *} p<0.01,{ }^{* * *} p<0.001$.

We now turn to the results for Germany (Figure 6). We find some evidence for H1, expecting party cues to affect the legitimacy beliefs of partisans. Among CDU/CSU partisans, we observe one positive and statistically significant treatment effect in the case of NATO, in line with $\mathrm{H} 1$. When CDU/CSU partisans are conveyed the message that the CDU/CSU parliamentary group advocates an increase in the financial contribution to NATO, because of the organization's importance for peace, this affect their confidence in NATO positively when the issue is highly polarized. However, we also observe similar positive treatment effects among CDU/CSU partisans in the case of the UN, despite the expectation of negative effects from a treatment indicating the CDU/CSU parliamentary group to advocate a reduction in the need of refugees under the UN convention due to costs. We do not find any significant treatment effects for SPD partisans. 
There is no support for $\mathrm{H} 2$ in the German context. Party cues do not have a greater effect on respondents with a stronger partisan identification, regardless of whether we focus on CDU/CSU or SPD partisans, and regardless of whether we explore this expectation in the context of NATO or the UN (see Appendix Tables D2 and D3).

Finally, we find some evidence in favor of $\mathrm{H} 3$, about a conditioning effect of issue polarization. Among CDU/CSU partisans, the endorsement of NATO as a preserver of peace, combined with high polarization of the issue (treatment 3 ), increases confidence in NATO by about 0.8 on the 11-point confidence scale, while there is no effect in the context of low polarization (treatment 2), which corroborates H3. Similarly, party cues about the UN's role as a protector of refugees increases CDU/CSU partisans' confidence in NATO with more than 1 on the 11-point scale under high polarization, but only about 0.9 in a low polarization environment. Yet, as observed above, the original expectation was negative rather than positive effects of these treatments for CDU/CSU partisans. We do not find effects consistent with $\mathrm{H} 3$ among SPD partisans.

Taken together, we find strong support for $\mathrm{H} 1$ on general party cue effects among Democrats in the US, but no support among Republicans in the US or among CDU/CSU and SPD partisans in Germany. $\mathrm{H} 2$ on a conditional effect of partisan identification receives support among Democrats in the US in the context of NATO, but not in the context of the UN, and not for other partisans in the two countries. H3 on a conditional effect of issue polarization receives support among Republicans and CSU/CDU partisans in the context of NATO, but not among Democrats and SPD partisans in relation to any of the two IOs. 


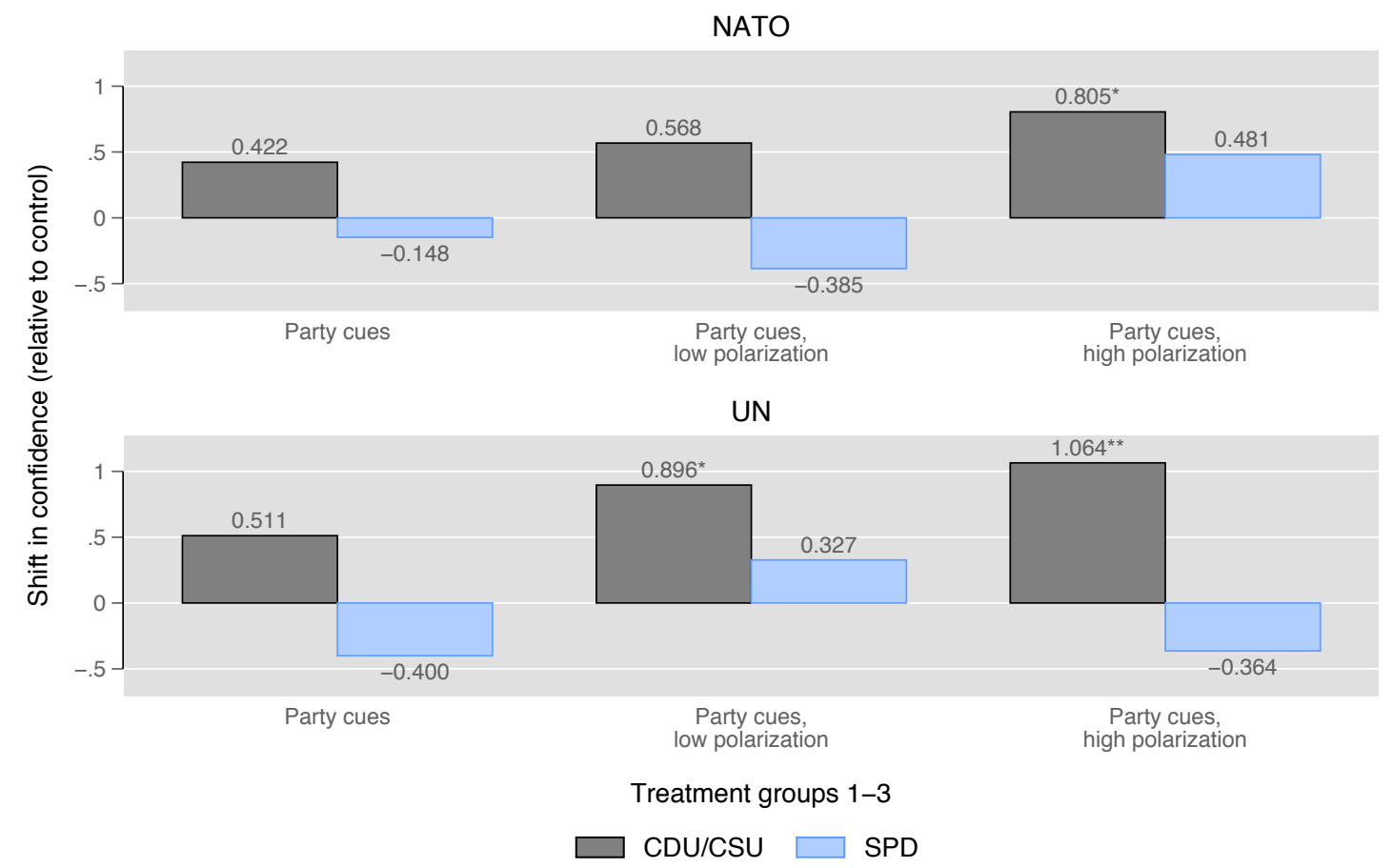

Figure 6. Treatment effects in Germany

Notes: Treatment group 1 received issue frame and party endorsement; group 2 received issue frame and party endorsement in a low polarization environment; and group 3 received issue frame and party endorsement in a high polarization environment. Significance levels: ${ }^{*} p<0.05,{ }^{* *} p<0.01,{ }^{* * *} p<0.001$.

\section{Robustness and validity checks}

To test the validity of the data, we performed balance tests. Specifically, we examined whether eight different individual characteristics measured in the survey, including age, gender, education and social trust, are evenly distributed across the conditions we aggregated for the analysis. The results increase our confidence in the randomization of the subjects among treatment groups. We only discover imbalances in one of the 48 tests (see Appendix Table E1).

In addition, we performed a number of robustness tests, which corroborate the main results. First, we included a series of manipulation checks to test if respondents had properly registered the information on party endorsements and level of polarization. Respondents in 
treatment group 1 were asked to identify the main argument of the two parties on the issue in question. In addition, respondents in treatment groups 2 and 3 were asked to identify the degree of party polarization on the issue in question. In the US, where the political climate is more polarized and people thus may be more alert to information about party positions, the manipulation checks worked better. In the context of NATO, on average almost 79 percent of respondents correctly recalled the pro and con positions of the Republicans and 82 percent the positions of the Democrats. In the context of the UN, on average almost 83 percent of respondents correctly recalled the pro and con positions of the Republicans and 82 percent the positions of the Democrats. We also asked respondents if they recalled the level of polarization between the two political parties on the issues of migration and security. About 75 percent of the respondents correctly recalled high polarization, while only about 38 percent correctly recalled low polarization in the context of NATO. About 85 percent of the respondents correctly recalled high polarization, while only about 30 percent correctly recalled low polarization in the context of the UN. Moreover, the results from $t$-tests of the polarization comprehension checks confirmed for both experiments that both of our polarization conditions prompted significantly higher perceptions of polarization $(N=820$, $p<0.000$ for both experiments).

In Germany, manipulation checks yielded somewhat weaker results. In the context of NATO, on average 70 percent of respondents correctly recalled the pro and con positions of the CDU/CSU and 75 percent the positions of the SPD. In the context of the UN, however, much fewer respondents correctly recalled party endorsements, which may have to do with the less clear partisan divide between the CDU/CSU and the SDP on this issue in public debate. About 25 percent correctly recalled the CDU/CSU position, while about 30 percent correctly recalled the SDP position. When we further asked respondents across conditions about the extent to which they thought the parties were polarized, recall accuracy in the 
context of NATO was 58 percent for the weakly polarized condition and 66 percent for the highly polarized condition. In the context of the UN, 58 percent correctly recalled low polarization and 68 percent high polarization. The results from $t$-tests of the polarization comprehension checks for both experiments confirmed that our high polarization prompts led to significantly higher perceptions of polarization ( $N=804, p<0.001$ for both experiments).

Given these results from the manipulation checks, it is warranted to test for the robustness of the results by re-analyzing the results from Figures 5 (US) and 6 (Germany) only using the answers of those who passed at least one of two manipulation tests about the partisan endorsements per experiment. The results are robust throughout with one exception: In Germany, the NATO cue in a highly polarized context (treatment group 3) does not affect the confidence of CDU/CSU partisans in NATO (see Appendix Tables E2-E3).

Second, we checked whether treatment effects differ among those who have more negative or positive pre-treatment opinions of democracy and effectiveness in the two IOs. All treatment effects are larger in size among those with more positive opinions of the two IOs compared to those with more negative opinions. This result holds in both countries. Thus, respondents who already have a positive impression of IOs react more strongly to party cues about IOs (see Appendix Figures E1-E2).

Third, we checked whether treatment effect size differs depending on pre-treatment attitudes toward defense spending and refugees. In the US, treatment effects on UN confidence are larger in size among those who think that accepting refugees is a moral obligation of the US. In the context of NATO, treatment effect size is not different among people with varying positions on whether defense spending should be prioritized. In Germany, effects depend on pre-treatment attitudes across the board. Treatment effects on confidence in NATO are consistently stronger among those who agree defense spending should be prioritized, and treatment effects on confidence in the UN are consistently stronger 
among those who agree accepting refugees is a moral obligation of Germany (see Appendix Figures E3-E4). In sum, citizens who already care more deeply about the two issues, also tend to be more receptive to party cues on these matters.

Finally, we checked whether treatment effect size depends on confidence in government and political awareness. With regard to confidence in government, treatment effects are stronger among those who have relatively more confidence in government in both countries (see Appendix Figures E5-E6). With regard to political awareness, tests using the two indicators of education and knowledge regarding global governance suggest that treatment effects among Democrats are stronger among the politically aware. Such a contingent effect was not found for Republicans. In Germany, results are not found to depend on political awareness (see Appendix Figures E7-E10).

\section{Discussion and Conclusion}

Taken together, our results suggest that citizens draw on party cues when developing legitimacy beliefs toward IOs, but that these effects vary across political contexts and individual outlooks. The effects are stronger in countries which are more polarized politically and among citizens with more positive attitudes toward international cooperation. The two experiments found that party cues mattered almost exclusively in the US, and then mainly among Democrats, while Republicans appeared less easily swayed. The experiments also offered mixed support for the expectations that party cue effects depend on the strength of citizens' partisan identification and the polarization of the issue between and within political parties. However, examining pre-treatment opinions closely, the robustness checks contributed important insights, partly correcting the more negative findings in the main analysis. Specifically, it appears that party cues have effects on citizens in both countries, 
sympathizing with both parties, when these citizens already have more positive opinions of NATO and the UN and more positive views of the issues at hand.

How can we understand these findings? Our findings prompt four observations. First, why do party cues appear to have stronger effects on people's legitimacy beliefs in the US compared to Germany? We attribute this variation in effects across the two countries in part to variation in the degree of political polarization across the two countries, both in terms of party system polarization and mass polarization. ${ }^{3}$ The US two-party system is considerably more polarized than the German multi-party system, in the sense that parties are ideologically more differentiated in the US than in Germany (Dalton 2008). In the more polarized system, the positions of the parties are more distinguishable from one another, and thus clearer and less ambiguous as cues for their partisans (Levendusky 2010; Druckman et al. 2013). Thus, the differences between the two sets of party cues were likely more credible in the US than in Germany, as indicated by the stronger recollection of party endorsements among US respondents (see robustness checks).

In addition, public opinion in the US is more ideologically polarized than in Germany (Lupu 2015). When the public is more clearly divided in ideological terms, citizens are also more likely to listen to their favored political party when it conveys messages that conflict with those of parties on the other side of the spectrum. This polarization extends to respondents' pre-treatment opinions of the two IOs. While pre-treatment beliefs about whether the UN works democratically and effectively did not differ among CDU/CSU and SPD partisans in Germany, they clearly do in the US among Democrats and Republicans. And while pre-treatment beliefs about how well NATO works differed among CDU/CSU and SPD partisans in Germany, they do so to a much larger extent in the US among Democrats and Republicans.

\footnotetext{
${ }^{3}$ In addition, this cross-country pattern may have been reinforced by less statistical power in the case of Germany, as there are fewer CDU/CSU and SPD partisans in Germany than there are Democratic and Republican partisans in the US (Figure 1).
} 
Second, how come party cues worked better in shaping the opinions of partisans identifying with some political parties than others? In the US, the results show a dramatic difference between Democrats and Republicans in terms of cueing effects on legitimacy beliefs, while in Germany, such effects are more common for CDU/CSU partisans compared to SPD partisans, although sometimes in the opposite direction than expected. In the US case, one reason might be found in the pre-treatment opinions toward IOs. As revealed by the robustness tests, party cues had considerably stronger effects on citizens who already had a positive opinion of these two IOs, and those citizens were on average much more common among Democratic partisans. This interpretation is further supported by the fact that the only example of a party cue effect among Republications is found in the context of NATO, which Republicans tend to view more favorably.

In the German case, the differences in pre-treatment opinions between CDU/CSU and SPD partisans are non-existent regarding the UN and small regarding NATO, and thus offer little help in accounting for the greater sensitivity of CDU/CSU partisans to party cues. The puzzling finding that CDU/CSU partisans move in the opposite direction from the party cue on the UN migration regime may be explained by the relatively high support among these partisans for the $\mathrm{UN}$ as an organization and for the notion that Germany has a moral obligation to accept refugees (see Figure 4), which may have trumped the economic concerns emphasized in the party cue. Such effects are not uncommon, and usually interpreted as issue substance outweighing party cues (Bullock 2011; Nicholson 2011; Druckman et al. 2013).

Third, what may account for party cues being more effective in relation to some issues than others? In both countries, party cues about military spending in the context of NATO had stronger effects than party cues about migration in the context of the UN. However, this pattern may very well be due to different reasons in the two countries. In the US, Democratic and Republican partisans are already positioned exceptionally far from each other in terms of 
pre-treatment opinions toward the UN and the obligation to accept refugees (Figure 3). The already extreme positions of partisans on this issue mean that the room for further shifts in opinion toward the end of the spectrum is limited. It may also be that these extreme positions of partisans are anchored, making further movements less likely and far-reaching (Tversky and Kahneman 1974). In Germany, conversely, the media content analysis and the manipulation check suggest that the ineffectiveness of the UN cues may be due to the limited differences between the two main parties on this issue in the public debate, making the treatments less credible and the party cues more difficult to recall.

Fourth, the findings reported in the robustness tests suggest that some citizens are more responsive to party cues than others, irrespective of country, partisan identity, and issue focus. In both countries, people with more positive opinions toward these IOs and issues to start with were more receptive to party cues. This suggests that people who think of IOs as relevant governing institutions, and who care about the issues at stake, also are willing and able to integrate new information about these organizations and issues from parties they sympathize with.

These findings suggest three broader implications. First, they indicate that party cue effects in general may be weaker on global issues compared to domestic issues. While it would have been reasonable to expect that citizens would rely more on party cues on global issues they know less well, the mixed picture in our findings suggests the opposite, possibly because global issues often are less politicized than domestic issues. The stronger effects of party cues established in the context of US politics (e.g., Levendusky 2010; Druckman et al. 2013) and European politics (e.g., Maier et al. 2012; Torcal et al. 2018) may thus be due to greater politicization and polarization of these issues among parties and the mass public compared to the legitimacy of IOs. 
Second, our findings highlight the importance of extending experiments on elite cueing beyond single-country settings, particularly the US. Most experiments on the effects of elite cueing on public opinion toward international issues and institutions focus exclusively on the US (e.g., Hiscox 2006; Berinsky 2009; Guisinger and Saunders 2017). The same goes for the large literature on elite cueing in the context of American politics, of course (e.g., Levendusky 2010; Bullock 2011; Druckman et al. 2013; Broockman and Butler 2017). This paper points to the perils of this strategy, as the US is a very particular case, due to the high level of polarization in the party system and the mass public. We can only expect findings from the US setting to travel to those rare contexts which share these features; in other contexts, the effects of elite cueing may very well be weaker.

Third, our findings suggest that domestic political elites play an important, albeit varying, role in citizens' development of legitimacy beliefs toward IOs. While earlier research has established that communication by international elites, in the shape of NGOs, member states, and IOs themselves, affect the perceived legitimacy of IOs (Dellmuth and Tallberg 2020), this paper shows that party elites may have a similar impact. As political parties engage in growing contestation over IOs, challenging and defending their authority (De Vries et al. forthcoming), citizens will take notice, especially when they care about international cooperation. Partisan politics is not divorced from the legitimacy of IOs, but a force shaping its future development.

\section{References}

Abramowitz, Alan I. 2010. The Disappearing Center: Engaged Citizens, Polarization, and American Democracy. New Haven, CT: Yale University Press. 
Berinsky, Adam J. 2009. In Time of War. Understanding American Public Opinion from World War II to Iraq. Chicago, IL: Chicago University Press.

Binder, Martin, and Monika Heupel. 2015. The Legitimacy of the UN Security Council: Evidence from Recent General Assembly Debates. International Studies Quarterly 59(2): $238-250$.

Bisgaard, Martin, and Rune Slothuus. 2018. Partisan Elites as Culprits: How Party Cues Shape Partisan Perceptual Gaps. American Journal of Political Science 62(2): 456-469.

Broockman, David E., and Daniel M. Butler. 2017. The Causal Effects of Elite PositionTaking on Voter Attitudes: Field Experiments with Elite Communication. American Journal of Political Science 61(1): 208-221.

Buchanan, Allen, and Robert O. Keohane. 2006. The Legitimacy of Global Governance Institutions. Ethics \& Global Politics 20(4): 405-437.

Bühlmann, Marc, and Ruth Kunz. 2011. Confidence in the Judiciary: Comparing the Independence and Legitimacy of Judicial Systems. West European Politics 34(2): $317-$ 345.

Bullock John G. 2011. Elite Influence on Public Opinion in an Informed Electorate. American Political Science Review 105(3): 496-515.

Busby, Ethan, D. J. Flynn, and James N. Druckman. 2018. Studying Framing Effects on Political Preferences.” In Doing News Framing Analysis II, edited by Paul D’Angelo, 27-50. London: Routledge.

Caldeira, Gregory A. 1986. Neither the Purse Nor the Sword: Dynamics of Public Confidence in the Supreme Court. American Political Science Review 80(4): 1209-1226.

Campbell, Angus, Philip. E. Converse, Warren. E. Miller, and Donald. E. Stokes. 1960. The American Voter. New York: Wiley. 
Carmines, Edward G. and James H Kuklinski. 1990. Incentives, Opportunities, and the Logic of Public Opinion in American Political Representation. In Information and Democratic Processes, edited by John A. Ferejohn and James H. Kuklinski, 240-268. Urbana, IL: University of Illinois Press.

Cavari, Amnon, and Guy Freedman. 2019. Partisan Cues and Opinion Formation on Foreign Policy. American Politics Research 47(1): 29-57.

Chong, Dennis, and James N. Druckman. 2007. Framing Theory. Annual Review of Political Science 10: 103-126.

Dalton, Russel J. 2008. The Quantity and the Quality of Party Systems: Party System Polarization, Its Measurement, and Its Consequences. Comparative Political Studies 41(7): 899.

Dellmuth, Lisa M., and Jonas Tallberg. 2015. The Social Legitimacy of International Organisations: Interest Representation, Institutional Performance, and Confidence Extrapolation in the United Nations. Review of International Studies 41(3): 451-475.

Dellmuth, Lisa M., and Jonas Tallberg. 2020. Elite Communication and the Popular Legitimacy of International Organizations. British Journal of Political Science online first.

De Vries, Catherine E., Sara B. Hobolt, and Stefanie Walter. Forthcoming. Politicizing International Cooperation: The Mass Public, Political Entrepreneurs, and Political Opportunity Structures. International Organization forthcoming.

Dingwerth, Klaus, Antonia Witt, Ina Lehmann, Ellen Reichel, and Tobias Weise. 2019. International Organizations Under Pressure: Legitimating Global Governance in Challenging Times. Oxford: Oxford University Press. 
Druckman, James N., Erik Peterson, and Rune Slothuus. 2013. How Elite Partisan Polarization Affects Public Opinion Formation. American Political Science Review 107(1): 57-79.

Druckman, James N., and Arthur Lupia. 2000. Preference Formation. Annual Review of Political Science 3: 1-24.

Ecker-Ehrhardt, Matthias. 2018. Self-Legitimation in the Face of Politicization: Why International Organizations Centralized Public Communication. Review of International Organizations 13(4): 519-546.

Gibson, James L., Gregory A. Caldeira, and Lester Kenyatta Spence. 2003. Measuring Attitudes Toward the United States Supreme Court. American Journal of Political Science 47(2): 354-367.

Gilley, Bruce. 2006. The Meaning and Measure of State Legitimacy: Results for 72 Countries. European Journal of Political Research 45(3): 499-525.

Goren, Paul, Christopher M. Federico, and Miki Caul Kittilson. 2009. Source Cues, Partisan Identities, and Political Value Expression. American Journal of Political Science 55: $805-820$.

Gregoratti, Catia, and Anders Uhlin. 2018. Civil Society Protest and the (De)Legitimation of Global Governance Institutions. In Legitimacy in Global Governance: Sources, Processes, and Consequences, edited by Jonas Tallberg, Karin Bäckstrand, and Jan Aart Scholte, 134-152. Oxford: Oxford University Press.

Gronau, Jennifer, and Henning Schmidtke. 2016. The Quest for Legitimacy in World Politics - International Institutions' Legitimation Strategies. Review of International Studies 42(3): 535-557. 
Guisinger, Alexandra, and Elizabeth N. Saunders. 2017. Mapping the Boundaries of Elite Cues: How Elites Shape Mass Opinion Across International Issues. International Studies Quarterly 61: 425-441.

Hiscox, Michael J. 2006. Through a Glass and Darkly: Attitudes Toward International Trade and the Curious Effects of Issue Framing. International Organization 60: 755-780.

Hooghe, Liesbet, and Gary Marks. 2005. Calculation, Community and Cues: Public Opinion on European Integration. European Union Politics 6(4): 419-443.

Hurd, Ian. 2007. After Anarchy: Legitimacy and Power in the United Nations Security Council. Princeton, NJ: Princeton University Press.

Inglehart, Ronald, and Christian Welzel. 2005. Modernization, Cultural Change, and Democracy: The Human Development Sequence. Cambridge: Cambridge University Press.

Kalm, Sara, and Anders Uhlin. 2015. Civil Society and the Governance of Development: Opposing Global Institutions. Basingstoke: Palgrave Macmillan.

Lau, Richard R., and David P. Redlawsk. 2001. Advantages and Disadvantages of Cognitive Heuristics in Political Decision Making. American Journal of Political Science 45(4): 951-971.

Lavine, Howard, Christopher Johnston, and Marco Steenbergen. 2012. The Ambivalent Partisan. Oxford: Oxford University Press.

Leeper, Thomas J., and Rune Slothuus. 2010. Political Parties, Motivated Reasoning, and Public Opinion Formation. Advances in Political Psychology 35(1): 129-156.

Levendusky, Matthew S. 2010. Clearer Cues, More Consistent Voters. Political Behavior 32(1): 111-31.

Lupu, Noam. 2015. Party Polarization and Mass Partisanship: A Comparative Perspective. Political Behavior 37: 331-356. 
Maier, Michael, Silke Adam, and Jürgen Maier. 2012. The Impact of Identity and Economic Cues on Citizens' EU Support: An Experimental Study on the Effects of Party Communication in the Run-up to the 2009 European Parliament Elections. European Union Politics 13(4): 580-603.

Maliniak, Daniel, Erik Parajon, and Ryan Powers. 2020. Epistemic Communities and Public Support for the Paris Agreement on Climate Change. Political Research Quarterly online first.

Morse, Julia C., and Robert O. Keohane. 2014. Contested Multilateralism. Review of International Organizations 9(4): 385-412.

Newton, Kenneth, and Pippa Norris. 2000. Confidence in Public Institutions: Faith, Culture or Performance? In Disaffected Democracies: What's Troubling the Trilateral Countries?, edited by Susan J. Pharr and Robert D. Putnam, 52-73. Princeton, NJ: Princeton University Press.

Nicholson, Stephen P. 2011. Dominating Cues and the Limits of Elite Influence. Journal of Politics 73(4): 1165-1177.

Nicholson, Stephen P. 2012. Polarizing Cues. American Journal of Political Science 56(1): $52-66$.

Norris, Pippa. 2009. Confidence in the United Nations: Cosmopolitan and Nationalistic Attitudes. In The International System, Democracy, and Values, edited by Yilmaz Esmer and Thorleif Pettersson, 17-48. Uppsala: Acta Universitatis Upsaliensis.

O’Brien, Robert, Anne Marie Goetz, Jan Aart Scholte, and Marc Williams. 2000. Contesting Global Governance: Multilateral Economic Institutions and Global Social Movements. Cambridge: Cambridge University Press. 
Pew Research Center. 2014. Political Polarization in the American Public. Available at: https://www.pewresearch.org/politics/2014/06/12/political-polarization-in-theamerican-public/

Putnam, Robert D. 1988. Diplomacy and Domestic Politics: The Logic of Two-Level Games. International Organization 42(3): 427-460.

Rocabert, Jofre, Frank Schimmelfennig, Loriana Crasnic, and Thomas Winzen. 2019. The Rise of International Parliamentary Institutions: Purpose and Legitimation. Review of International Organizations 14: 607-631.

Slothuus, Rune, and Claes H. de Vreese. 2010. Political Parties, Motivated Reasoning, and Issue Framing Effects.”Journal of Politics 72(3): 630-645

Sniderman, Paul M. 2000. Taking Sides: A Fixed Choice Theory of Political Reasoning. In Elements of Reason: Cognition, Choice, and the Bounds of Rationality, edited by Arthur Lupia, Mathew D. McCubbins, and Samuel L. Popkin, 67-84. New York: Cambridge University Press.

Sniderman, Paul M., Richard A. Brody, and Philip E. Tetlock. 1991. Reasoning and Choice: Explorations in Political Psychology. Cambridge: Cambridge University Press.

Steffek, Jens. 2003. The Legitimation of International Governance: A Discourse Approach. European Journal of International Relations 9(2): 249-275.

Stephen, Matthew D. and Michael Zürn. 2019, eds. Contested World Orders: Rising Powers, Non-Governmental Organizations, and the Politics of Authority Beyond the NationState. Oxford: Oxford University Press.

Taber, Charles S., and Milton Lodge. 2006. Motivated Skepticism in the Evaluation of Political Beliefs. American Journal of Political Science 50: 755-769.

Transue, John E., and Daniel J. Lee, and John H. Aldrich. 2009. Treatment Spillover Effects Across Survey Experiments. Political Analysis 17(2): 143-61. 
Tallberg, Jonas, Karin Bäckstrand, and Jan Aart Scholte, eds. 2018. Legitimacy in Global Governance: Sources, Processes, and Consequences. Oxford: Oxford University Press. Tallberg, Jonas, and Michael Zürn. 2019. The Legitimacy and Legitimation of International Organizations: Introduction and Framework. Review of International Organizations 14(4): 581-606.

Torcal, Mariano, Sergio Martini, and Lluis Orriols. 2018. Deciding about the Unknown: The Effect of Party and Ideological Cues on Forming Opinions about the European Union. European Union Politics 19(3): 502-523.

Tversky, Amos, and Daniel Kahneman. 1974. Judgment under Uncertainty: Heuristics and Biases. Science 185(4157): 1124-1131.

Voeten, Erik. 2013. Public Opinion and the Legitimacy of International Courts. Theoretical Inquiries in Law 14(2): 411-436.

von Billerbeck, Sarah. 2020. "Mirror, Mirror on the Wall”: Self-Legitimation by International Organizations. International Studies Quarterly 64(1): 207-219.

Zaum, Dominik. Ed. 2013. Legitimating International Organizations. Oxford: Oxford University Press.

Zaller, John R. 1992. The Nature and Origins of Mass Opinion. New York: Cambridge University Press.

Zürn, Michael. 2018. A Theory of Global Governance: Authority, Legitimacy, and Contestation. Oxford: Oxford University Press. 